\title{
Effects of Empty Fruit Bunch (EFB) Application on Oil Palm Yield, Soil Properties and Cost- Benefits Analysis
}

\author{
Che Ku Hafeez C.K. Denang1,2, Daljit S. Karam², , A. Arifin³, Keeren S. Rajoo \\ ${ }^{1}$ Ladang Rakyat Trengganu Sdn. Bhd, Cheneh, Terengganu - 24000, Malaysia. \\ ${ }^{2}$ Department of Land Management, Faculty of Agriculture, UPM, Serdang, Selangor -43400, Malaysia. \\ ${ }^{3}$ Department of Forestry Science and Biodiversity, Faculty of Forestry, UPM, Selangor -43400, Malaysia. \\ ${ }^{4}$ Tree Improvement Programme, FRIM, Kepong, Selangor -68100, Malaysia.
}

\section{A R T I C LE DE T A I L S}

Article history:

Received 30 November 2020

Accepted 13 December 2020

Available online 15 December 2020

\section{Keywords:}

Oil Palm Yield

Soil Properties

Empty Fruit Bunches (EFB)

Root Biomass

\begin{abstract}
A B S T R A C T
Due to limited area for dumping empty fruit bunch (EFB), an environmentally sustainable approach of EFB utilization is needed in oil palm plantations. The estimated production of EFB generated from 100 tons of fresh fruit bunches (FFB) is about $20 \%$, which is equivalent to 20 tons. A study was conducted in 2015 at an 8-year-old oil palm estate owned by Ladang Rakyat Trengganu Sdn. Bhd. (LRTSB), located in Cheneh, Terengganu. It is estimated that the LRTSB palm oil mill's annual production is about 240000 - 250000 tons of FFB that will produce about 48000 - 50000 tons of EFB. In this research, the application of EFB at different rates of $60 \mathrm{t} / \mathrm{ha}$ (T1), $80 \mathrm{t} / \mathrm{ha}$ (T2) and $0 \mathrm{t} / \mathrm{ha}$ (T3) were conducted from 2015-2019. The EFB was applied along the frond heap (alternate row), once a year. The data collected consisted of oil palm yield, soil chemical properties and cost benefit analysis. Results showed that after 6 years of EFB application, the oil palm yield increased when compared to the plot without EFB application. In addition, the EFB helped in increasing soil nutrient content, moisture and reduced soil compaction. In short, application of EFB increased soil fertility and improved oil palm yield.
\end{abstract}

\section{Introduction}

Malaysia and Indonesia are the largest palm oil producer of the world, supplying more than $90 \%$ of total global palm oil production. The main importer for Indonesia palm oil is India and China, while for Malaysia they are the European Union, Pakistan, China, USA and India [1]. There are about 5.85 million ha of oil palm plantation in Malaysia as of 2015, which is represented by the plantation sector $(72 \%)$, independent smallholders $(17 \%)$, followed by organized smallholders (12\%). The total national fresh fruit bunch (FFB) production is $17.16 \mathrm{t} / \mathrm{ha}$ which is equal to 100.37 million metric tons produced throughout the year [2]. In addition, Syed-Mahdhar [3] stated that for every 100 metric tonnes of FFB processed at the mill, it will produce at least 20 tonnes of empty fruit bunch (EFB), which equals to $20 \%$ of EFB production [4]. Hence, based on the national FFB production, it is estimated that EFB is produced at about 2 million tons. The fiber and kernel of EFB are sometimes used as boiler fuel for energy production. However, few mills still consider EFB as waste.

Improper management of EFB will lead to environmental problems. Hence, there is a need for an environmentally-friendly approach to managing EFB. EFB is widely used as a mulching material in the plantations as it provides nutrients and moisture to the soil [5]. EFB application can also improve soil structure, leading to better aeration, increased water holding capacity and increase in soil $\mathrm{pH}[6,7]$. Therefore, the usage of EFB as a mulching for the improvement of soil properties is highly recommended.

At Ladang Rakyat Trengganu Sdn. Bhd., the total EFB production per year ranges from $240000-250000$ tones. At the rate of $60-80 \mathrm{t} / \mathrm{ha}$ of EFB application, it can use a mulching material for up to 4000 ha of area per year. This approach helps to reduce dumping area for EFB. Besides reducing environmental pollution, the EFB can be utilized as other organic material-based product such as planting medium for oil palm nurseries, mulching in new planting area and even organic fertilizers.

The objective of the current research was to determine the optimum application rate of EFB to increase oil palm yield, root biomass and selected soil chemical properties at Ladang Rakyat Trengganu plantation.

\section{Experimental Methods}

\subsection{Study Sites}

The research was carried out at Paloh Jenang Estate, Ladang Rakyat Trengganu Sdn. Bhd. (LRTSB) $\left(4.1706^{\circ} \mathrm{N}, 103.2243^{\circ} \mathrm{E}\right)$. The area was categorized as a moderate to wet region with annual rainfall distribution of $2000 \mathrm{~mm}$ up to $3953 \mathrm{~mm}$. The topography in the study plots were mainly gently undulating to hilly. The soil series at the study plots is Gong Chenak (USDA Taxonomy: Plintaquic Paleudult, clayey, kaolinitic isohyperthermic).

\subsection{Experimental Layout and Treatment Leve}

Treatment used in this study were 60 EFB t/ha (T1), 80 EFB t/ha (T2) and $0 \mathrm{t} / \mathrm{ha}$ (T3). The EFB was applied around the frond heap area in alternate row. The NPK fertilizer were also applied at standard amount for each treatment level for each oil palm tree included in the study. In the T1 and T2, the NPK fertilizer was applied on top of the EFB layer, while NPK fertilizer was applied on the weeded circle area for T1. The oil palm tree in each study plot was 8 years old as of 2014. Experimental layout of the study is presented in Table 1 and Fig. 1 shows the application of EFB in the estate.

Table 1 Experimental layout and treatment level

\begin{tabular}{|c|c|c|c|c|c|}
\hline Treatment & Label & $\begin{array}{l}\text { EFB } \\
\text { placement }\end{array}$ & $\begin{array}{l}\text { Frequency of } \\
\text { application }\end{array}$ & $\begin{array}{l}\text { Inorganic } \\
\text { fertilizer }\end{array}$ & $\begin{array}{l}\text { Fertilizer } \\
\text { area }\end{array}$ \\
\hline 60 t/ha & $\mathrm{T} 1$ & Frond & Once in a & \multirow{3}{*}{$\begin{array}{l}\text { NPK } \\
\text { fertilizer (12 } \\
\mathrm{kg} / \text { palm) }\end{array}$} & On top of \\
\hline 80 t/ha & $\mathrm{T} 2$ & heap & year & & EFB layer \\
\hline $0 \mathrm{t} / \mathrm{ha}$ & T3 & Nil & Nil & & $\begin{array}{l}\text { Weeded } \\
\text { circle }\end{array}$ \\
\hline
\end{tabular}

\subsection{Growth and Yield Performance of Oil Palm Tree}

The averaged bunch number $(\mathrm{ABN})$, average bunch weight (ABW) and yearly yield data were recorded from 2014 to 2019 and analysed. The weight of the oil palm fruit was weighed using $100 \mathrm{~kg}$ scales. The yearly yield of oil palm was grouped into 2014-2015 as pre-treatment period, while the yield from 2016-2019 were grouped as post treatment period. The oil palm root biomass was also measured. 

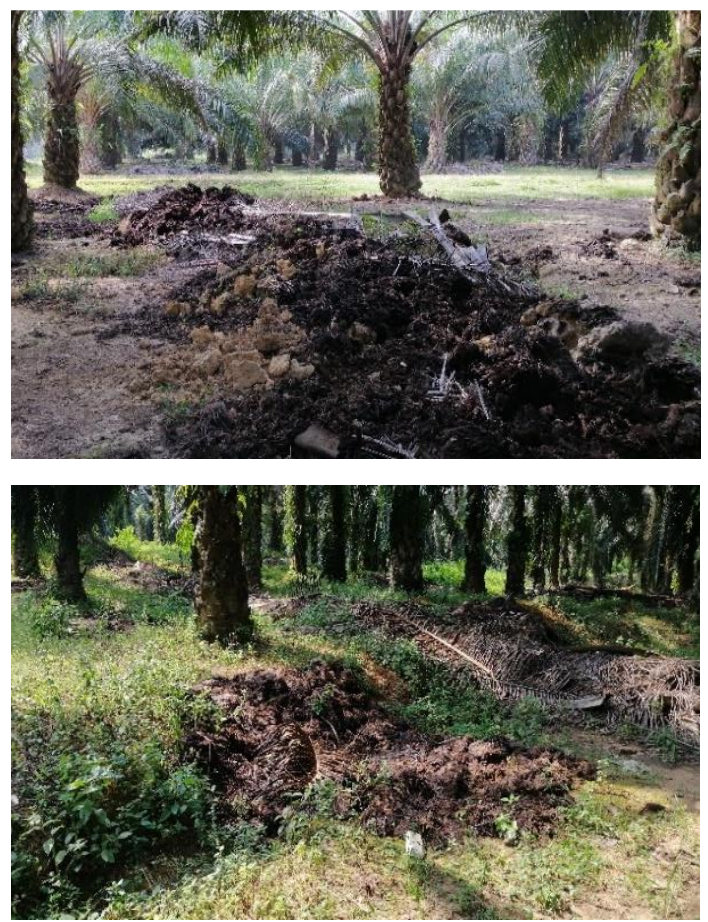

Fig. 1 Application area of EFB in oil palm plantation between the row of oil palm tree

\subsection{Soil Analyses}

Soil samples were collected on the EFB application area and weeded circle at each treatment plot at the depth of $0-30 \mathrm{~cm}$ using an Edelmann auger. The organic carbon (OC) and total nitrogen $(\mathrm{N})$, available phosphorus $(\mathrm{P})$, soil acidity $(\mathrm{pH})$, and cation exchange capacity were measured using standard soil analysis methods $[8,9]$.

\subsection{Statistical Analyses}

The experiment was carried out in Randomized Completely Block Design (RCBD). All the raw data were analyzed using ANOVA and their means were compared by the Tukey Test at $\mathrm{P} \leq 0.05$ using Statistical Analysis Software (SAS) version 9.2.

\section{Results and Discussion}

\subsection{Oil Palm Yield Performance}

Fig. 2 shows the results of oil palm yield. There was a positive increment for using EFB at $60 \mathrm{t} / \mathrm{ha}$ (T1) and EFB at $80 \mathrm{t} / \mathrm{ha}$ (T2). The yield of oil palm begun to increase after 2 years of continuous EFB application (Fig. 3). In contrast, the yield of oil palm in the control began to stagnate after two years of application. The highest oil palm yield was recorded in 2019, where T1 yield was $21.63 \mathrm{t} / \mathrm{ha}$ followed by T2 (19.34 t/ha) and T3 (15.34 t/ha). In 2018, the oil palm yield performance for all treatments dropped, which could be due to a drought season that occurred during $2015-2016$ and had affected the bunch development of oil palm.

The highest yield increment was recorded in T2, where $62 \%$ increment was recorded from $10.39 \mathrm{t} / \mathrm{ha}$ to $16.80 \mathrm{t} / \mathrm{ha}$. Increment in T1 was $54 \%$, from $12.01 \mathrm{t} /$ ha to $18.46 \mathrm{t} / \mathrm{ha}$ while the lowest is for T3 which is the non EFB plot where the increment is $16 \%$ from $11.42 \mathrm{t} / \mathrm{ha}$ to $13.29 \mathrm{t} / \mathrm{ha}$. The increment for post - treatment yield for T1 is $6.45 \mathrm{t} / \mathrm{ha}$ while for T2 is 6.41 $\mathrm{t} / \mathrm{ha}$ and for the control is $1.87 \mathrm{t} / \mathrm{ha}$. In addition, both treatments that used EFB increased 3.4 times better than the control plot. This shows that the application of EFB yearly at a constant rate can boost oil palm yield.

Table 2 Oil Palm Yield (2014-2019)

\begin{tabular}{|c|c|c|c|c|c|c|}
\hline $\begin{array}{l}\text { Treatme } \\
\text { nt }\end{array}$ & $\begin{array}{l}2014 \\
\text { (t/ha) }\end{array}$ & $\begin{array}{l}2015 \\
\text { (t/ha) }\end{array}$ & $\begin{array}{l}2016 \\
\text { (t/ha) }\end{array}$ & $\begin{array}{l}2017 \\
\text { (t/ha) }\end{array}$ & $\begin{array}{l}2018 \\
\text { (t/ha) }\end{array}$ & $\begin{array}{l}2019 \\
\text { (t/ha) }\end{array}$ \\
\hline $\mathrm{T} 1$ & $11.44 a$ & $12.59 \mathrm{a}$ & $16.19 a$ & $20.73 a$ & $15.31 \mathrm{~b}$ & $21.63 a$ \\
\hline $\mathrm{T} 2$ & $10.83 a$ & $9.76 b$ & $13.08 \mathrm{~b}$ & $18.44 \mathrm{~b}$ & $16.36 \mathrm{a}$ & $19.34 \mathrm{~b}$ \\
\hline T3 & $9.31 \mathrm{~b}$ & $13.52 \mathrm{a}$ & $12.67 \mathrm{~b}$ & $13.78 \mathrm{c}$ & $11.38 \mathrm{c}$ & $15.34 \mathrm{c}$ \\
\hline $\begin{array}{l}\text { Treat- } \\
\text { ment }\end{array}$ & $\begin{array}{l}\text { Pre } \\
(2014-2015\end{array}$ & \multicolumn{2}{|c|}{$\begin{array}{l}\text { Post } \\
(2016-2019)\end{array}$} & $\begin{array}{l}\text { Increment } \\
\text { (Pre vs Post }\end{array}$ & \multicolumn{2}{|c|}{$\begin{array}{ll}\text { Increment } \\
\text { over control }(\%)\end{array}$} \\
\hline $\mathrm{T} 1$ & $12.01 \mathrm{a}$ & \multicolumn{2}{|c|}{$18.46 a$} & 6.45 & \multicolumn{2}{|c|}{345} \\
\hline $\mathrm{T} 2$ & $10.39 \mathrm{c}$ & \multicolumn{2}{|c|}{$16.80 \mathrm{~b}$} & 6.41 & \multicolumn{2}{|c|}{343} \\
\hline T3 & $11.42 \mathrm{~b}$ & \multicolumn{2}{|c|}{$13.29 \mathrm{c}$} & 1.87 & \multicolumn{2}{|l|}{ - } \\
\hline
\end{tabular}

Note: Means within each column having different letters are significant different according to Tukey Test at 5\% level

https://doi.org/10.30799/jespr.208.20060301
Fig. 2 Oil palm yield

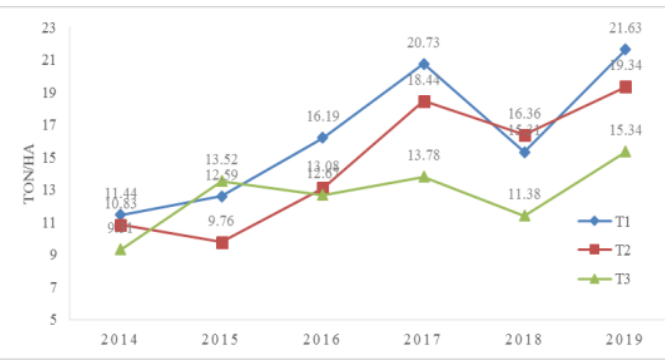

\subsection{Root Biomass}

The highest mean root dry mass was recorded for $\mathrm{T} 2$ at $56.50 \mathrm{grams} / \mathrm{ft}^{3}$, followed by T1 (47.19 grams/ft ${ }^{3}$ ) and T3 (29.06 gram/ft ${ }^{3}$ ) (Fig. 3).

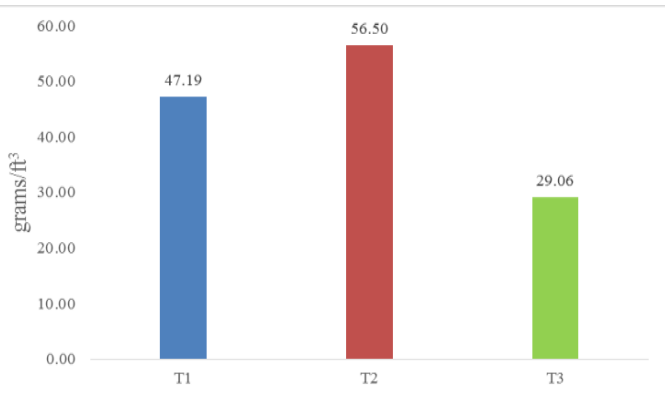

Fig. 3 Root dry biomass observation

\subsection{Soil Properties}

The application of EFB had improved soil chemical properties such as $\mathrm{pH}$, organic matter, total $\mathrm{N}$, available $\mathrm{P}$, cation exchangeable capacity (CEC) and exchangeable cation (Table 3). The degradation rate of EFB allowed more nitrogen to be released into the soil, and for Exchangeable $\mathrm{K}$ confirming that large quantities of $\mathrm{K}$ is available in the $\mathrm{EFB}$, made them ready for plant uptake [10]. The results showed that $\mathrm{T} 1$ had better soil chemical properties as compared to $\mathrm{T} 2$ and $\mathrm{T} 3$ for $\mathrm{pH}$, organic carbon, available phosphorus (P), exchangeable $\mathrm{Ca}$ and $\mathrm{Mg}$.

Table 3 Effect of six consecutive year of EFB application on soil chemical properties

\begin{tabular}{lllll}
\hline Treatment & $\mathrm{pH}$ & Organic C (\%) & Total N (\%) & $\begin{array}{l}\text { Available P } \\
\left(\mathrm{mg} \mathrm{kg}^{-1}\right)\end{array}$ \\
\hline $\mathrm{T} 1$ & $5.2 \mathrm{a}$ & $2.34 \mathrm{a}$ & $0.36 \mathrm{a}$ & $32 \mathrm{a}$ \\
$\mathrm{T} 2$ & $4.4 \mathrm{~b}$ & $1.73 \mathrm{ab}$ & $0.23 \mathrm{a}$ & $14 \mathrm{~b}$ \\
$\mathrm{~T} 3$ & $4.5 \mathrm{~b}$ & $0.98 \mathrm{~b}$ & $0.05 \mathrm{~b}$ & $7 \mathrm{~b}$ \\
\hline Treatment & $\mathrm{CEC}$ & \multicolumn{1}{c}{ Exchangeable } & $\mathrm{bases}\left(\mathrm{cmol}_{\mathrm{c}} \mathrm{kg}^{-1}\right)$ \\
& $\left(\mathrm{cmol}_{\mathrm{c}} \mathrm{kg}^{-1}\right)$ & $\mathrm{K}$ & $\mathrm{Ca}$ & $\mathrm{Mg}$ \\
\hline $\mathrm{T} 1$ & $11.54 \mathrm{a}$ & $1.30 \mathrm{a}$ & $2.55 \mathrm{a}$ & $1.67 \mathrm{a}$ \\
$\mathrm{T} 2$ & $12.94 \mathrm{a}$ & $0.83 \mathrm{a}$ & $1.82 \mathrm{ab}$ & $0.83 \mathrm{ab}$ \\
T3 & $7.38 \mathrm{~b}$ & $0.59 \mathrm{~b}$ & $1.09 \mathrm{~b}$ & $0.40 \mathrm{~b}$ \\
\hline Note: Mean within each column in with different letters are significantly difference at
\end{tabular}

Note: Mean within each column in with different letters are significantly difference at $5 \%$ level (Tukey Test).

\subsection{Effect of EFB Application on Oil Palm Yield}

There was significant different in effect of EFB application on the yield between pre- and post- treatment.

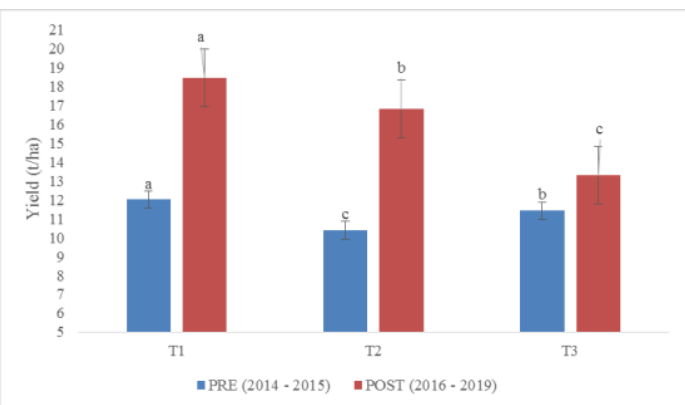

Fig. 4 Comparison of pre and post effect of EFB application on yield

For T1, the increment was about $6.45 \mathrm{t} / \mathrm{ha}$ which is from $12.01 \mathrm{t} / \mathrm{ha}$ to $18.46 \mathrm{t} / \mathrm{ha}$ and it was the highest increment recorded (Fig. 4). T3 remained the lowest yield increment at only $1.87 \mathrm{t} / \mathrm{ha}$, which is from $11.42 \mathrm{t} / \mathrm{ha}$ to $13.29 \mathrm{t} / \mathrm{ha}$. This result shows that the application of EFB improved oil 
palm yield performance up to 3 times. Similar finding recorded by Teo et al. [11] where the combination of EFB at the rate of at least $25 \mathrm{~kg} / \mathrm{palm}$ mixed with a standard amount of inorganic fertilizer will give better oil palm yield as compared to plots that only applied inorganic fertilizer. In addition, Rosenani et al. [12] showed that the application of EFB at the rate of $150 \mathrm{~kg} / \mathrm{palm} /$ year can be used as an alternative to chemical fertilizer.

\subsection{Effect of EFB on Soil Chemical Properties}

The result from Table 3 show that most of the treatment that were applied with EFB had better soil chemical properties as compared to the control plot. This is due to the additional nutrients supplied to the soil for oil palm tree uptake by the EFB. In addition, EFB is one of the only organic matter sources that benefits soil management by enhancing soil chemical properties and encouraging soil aeration. Moreover, continuous application of EFB increased the soil pH, organic matter, and CEC. The available $P$ at plots with EFB application also increased significantly, which could be attributed to the formation of phosphohumic [13]

\subsection{Effect of EFB Application on Root Density}

Root sampling was conducted at the depth of $1 \mathrm{ft} \times 1 \mathrm{ft} \times 1 \mathrm{ft}$ to represent the rhizosphere of the oil palm on the topsoil level (Fig. 5). The root in this study is divided into 2 classes which are coarse root and fine root. Fig. 6 shows that the T1 and T2 plots ha has good growth of roots as compared to T3. The same observation recorded by Teo et al. [11] by which the biomass of roots under EFB-compost was significantly higher of about $111 \%$ than section without EFB-compost. Feeder roots or the fine roots showed greatly positive response to the EFB which could be attributed to the ability of EFB to retain moisture and improve aeration. Therefore, providing favorable conditions such as extra moisture and less compact will be promoting more root growth and resulting better nutrient absorption.
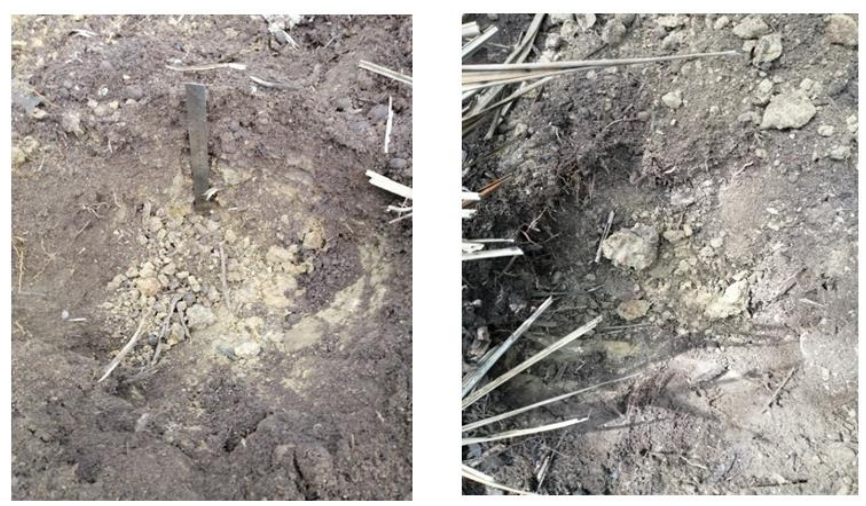

Fig. 5 The depth of soil where roots of oil palm tree were collected
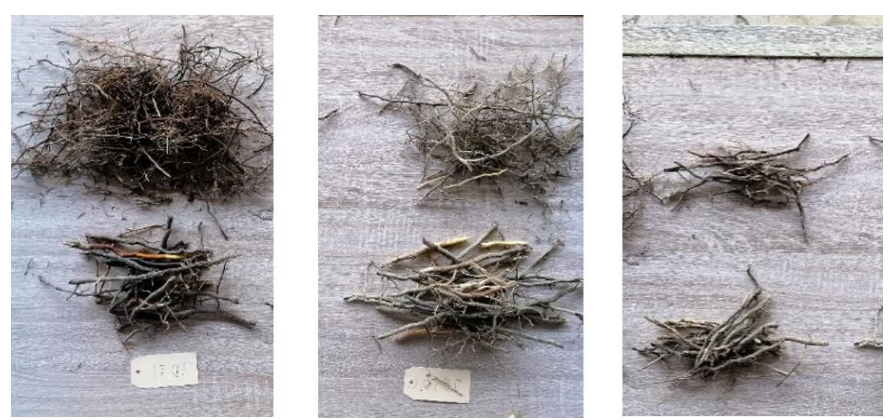

Fig. 6 roots sample collected from T1, T2 and T3 (left to right)

\subsection{Cost Benefit Analyses}

There was an increase in income generated through application of EFB in the oil palm plantation of LRSTB due to application of EFB (Table 4). The high fresh fruit bunches production in T1 and T2 generated positive income for LRSTB up to 3.4 times higher than T3 plot. The extra income generated by the yield of oil palm in T1 was RM 3,143 per ha while for T2 is RM 3,124 per ha (Table 4). Table 5 shows the net income obtained from EFB application in the estate of LRSTB. The application cost for EFB application is RM 10/ha which consists of transportation and EFB application cost. The total cost of EFB application for T1 was RM 600 per ha while for T2 is RM 800 per ha. The net income generated minus from the EFB application were shown in Table 5. To optimize the profit and reduce operational cost, the rate of $60 \mathrm{t} / \mathrm{ha}$ of EFB is sufficient to be applied in the oil palm plantation. In short, the EFB application on the oil palm plantation gave a positive impact on the oil palm yield, root biomass and selected soil chemical properties and helped reduce operational cost.

\begin{tabular}{|c|c|c|c|c|c|c|}
\hline $\begin{array}{l}\text { Treatme } \\
\text { nt }\end{array}$ & $\begin{array}{l}\text { Pre- } \\
\text { Yield } \\
\text { (t/ha) }\end{array}$ & $\begin{array}{l}\text { Post- } \\
\text { Yield } \\
\text { (t/ha) }\end{array}$ & $\begin{array}{l}\text { Incre- } \\
\text { ment } \\
\text { (t/ha) }\end{array}$ & $\begin{array}{l}{ }^{*} \text { Average } \\
\text { FFB } \\
\text { Price } \\
\text { (RM/Ton) }\end{array}$ & $\begin{array}{l}\text { Income } \\
\text { Generated } \\
(\mathrm{RM} / \mathrm{ha})\end{array}$ & $\begin{array}{l}\text { Income } \\
\text { Over } \\
\text { Control } \\
(\%)\end{array}$ \\
\hline $\mathrm{T} 1$ & 12.01 & 18.46 & 6.45 & 487 & 3143 & 345 \\
\hline $\mathrm{T} 2$ & 10.39 & 16.80 & 6.41 & 487 & 3124 & 343 \\
\hline T3 & 11.42 & 13.29 & 1.87 & 487 & 911 & - \\
\hline
\end{tabular}

Note: *Average FFB Price From 2017 - 2019

Table 5 Net income obtained through EFB application

\begin{tabular}{lllll}
\hline Treatment & $\begin{array}{l}\text { EFB } \\
\text { application } \\
\text { (RM/Ton) }\end{array}$ & $\begin{array}{l}\text { EFB Rate } \\
\text { (t/ha) }\end{array}$ & $\begin{array}{l}\text { Cost EFB } \\
\text { application/ha } \\
\text { (Rm/ha) (B) }\end{array}$ & $\begin{array}{l}\text { Net Income } \\
\text { (Rm/Ha) } \\
\text { (A - B) }\end{array}$ \\
\hline T1 & 10 & 60 & 600 & 2543 \\
T2 & 10 & 80 & 800 & 2324 \\
T3 & - & - & - & -
\end{tabular}

Note: Application cost 1: Transport cost from mill to estate; Application cost 2, application of EFB in estate (inter-row)

\section{Conclusion}

Oil palm yield increased with application of EFB. The trend of oil palm yield increment started after 20 - 24 months of EFB application. In addition, the application of EFB also increased the average bunch weight (ABW) for all EFB plot. Root dry mass for oil palm tree after EFB application was higher compared to no EFB application. In short, it can be concluded that the EFB application at the rate of $60 \mathrm{t} / \mathrm{ha}$ is recommended, as it is sufficient for promoting plant growth and improving soil fertility. As a recommendation, adding appropriate rate of NPK fertilizer will further enhance the efficiency of EFB. Further study needs to be conducted to determine the optimal amounts of NPK fertilizer that should be added to EFB. Moreover, the effects of long-term EFB application should also be conducted to determine whether the oil palm yield increment was consistent.

\section{References}

[1] B.E. Sawe, Top Palm Oil Producing Countries in the World, 2018. Retrieved from https://www.worldatlas.com/articles/top-palm-oil-producingcountries-in-the-world.html (Accessed on: 13 ${ }^{\text {th }}$ November 2020)

[2] R. Senawi, N.K. Rahman, N. Mansor, A. Kuntom, Transformation of oil palm independent smallholders through Malaysian sustainable Palm Oil, J. Oil Palm Res. 1 (2019) 1-12.

[3] S.H. Syed-Mahdhar, Compost and organic fertilizer from by product in oil palm plantation, National Seminar on Oil Palm, Kuala Lumpur, 2011, pp.87-93.

[4] G. Singh, D.L. Kow, K.C. Lim, S.G. Loong, Empty fruit bunches as mulch, In G. Singh, K.H. Teo, L.K. David (Eds.), Oil palm and the environment: A Malaysian perspective, Malaysia Oil Palm Growers' Council, Kuala Lumpur, 1999, pp.171183.

[5] C. Tang, Q. Yu, Chemical composition of legume residues and initial soil pH determine $\mathrm{pH}$ change of a soil incorporation of the residues, Plant Soil 215 (1999) 29-38.

[6] B. Trisakti, P. Mhardela, T. Husaini, Irvan, H. Daimon, Effect of pieces of empty fruit bunches (EFB) on composting of EFB mixed with activated liquid organic fertilizer, IOP Conf. Series: Mater. Sci. Eng. 309 (2018) 012093:1-9.

[7] R.A. Bakar, S.Z. Darus, S. Kulaseharan, N. Jamaluddin, Effects of ten year application of empty fruit bunches in an oil palm plantation on soil chemical properties, Nutr. Cycl. Agroecosys. 89 (2011) 341-349.

[8] D.S. Karam, A. Abdu, K.S. Rajoo, F.M. Muharam, M.R.K. Kasim, H.A. Hamid, Proposed soil quality index for rehabilitated tropical forest sites in Malaysia, Am. J. Appl. Sci. 14(1) (2016) 13-24.

[9] A. Arifin, D.S. Karam, J. Shamshuddin, N.M. Majid, O. Radziah, A.H. Hazandy, I. Zahari, Proposing a suitable soil quality index for natural, secondary and rehabilitated tropical forests in Malaysia, Afr. J. Biotech. 11(14) (2012) 32973309.

[10] C.E. Etta, R.N. Nkongho, I.N. Timti, C.N. Nebane, The effect of empty fruit bunch mulching applied as organic manure on the yield of oil palms planted on lateritic sandy soils of Pamol Ndian Estate, Cameroon, Presented at the Proceedings of the PIPOC International Palm Oil Congress, Agriculture, Biotechnology \& Sustainability, Kuala Lumpur, Malaysia, 2007.

[11] L.R. Teo, M. Shukri, K.P. Ong, A. Zainuriah, Alternative oil palm fertilizer sources and management - Oil Palm Bulletin, 2010. Retrieved from http://palmoilis.mpob.gov.my/OPB/index.php/2020/03/29/alternative-oilpalm-fertilizer-sources-and-management/ (Accessed on: 10 ${ }^{\text {th }}$ October 2020)

[12] A.B. Rosenani, S.Z. Darus, S. Kulaseharan, N. Jamaluddin, Effects of ten-year application of empty fruit bunches in an oil palm plantation on soil chemical properties, Nutr. Cycl. Agroecosys. 89(3) (2010) 341-349.

[13] N.O. Aisueni, U. Omoti, The role of compost in sustainable oil palm production, Proceeding of the 2001 - PIPOC International Palm Oil Congress, Malaysia, 2001, pp.536-541. 